\title{
Strong evidence supporting a relationship between colour pattern and apparent survival in common crossbills
}

\author{
Blanca Fernández-Eslava ${ }^{1,2}$ (1) $\cdot$ Daniel Alonso ${ }^{2} \cdot$ David Galicia $^{1} \cdot$ Juan Arizaga ${ }^{2}$
}

Received: 23 February 2021 / Revised: 6 August 2021 / Accepted: 21 August 2021 / Published online: 23 September 2021

(c) The Author(s) 2021

\begin{abstract}
Carotenoid staining has been repeatedly shown to serve as a sexually selected individual quality signal. In different species, individuals that show brighter carotenoid-based signals have been found to have superior feeding abilities, recover faster from disease, and generally enjoy better body condition. In the common crossbill (Loxia curvirostra), the colour has also been related to the different populations, with northern and central European populations being described as redder than those in the Mediterranean region. A study in the Pyrenees showed that long-winged individuals had lower apparent survival, and the proportion of red individuals was higher in long-winged birds, concluding that they could be nomadic birds (that travel long distances). A priori, if the red crossbills are more mobile than the yellow and orange ones, their apparent survival will be lower. However, in our study, red males showed a greater survival than males of other colours and almost double than that of the yellow ones. These results suggest that red coloration is linked to higher quality individuals regardless of their mobility.
\end{abstract}

Keywords Loxia $\cdot$ Colour and survival $\cdot$ Mediterranean crossbills $\cdot$ Carotenoids in birds

\section{Zusammenfassung}

\section{Starke Belege für einen Zusammenhang zwischen Farbmuster und Überleben beim Fichtenkreuzschnabel}

Die Farbgebung durch Carotinoide hat sich schon oft als ein geschlechtsspezifisches Signal für individuelle Qualität herausgestellt. Für unterschiedliche Tierarten hat man festgestellt, dass Individuen, die hellere, auf Carotinoiden basierende Farb-Signale aussenden, eine bessere Nahrungsaufnahme haben, sich schneller von Krankheiten erholen und allgemein in besserer körperlichen Verfassung sind. Beim Fichtenkreuzschnabel (Loxia curvirostra) wurde die Farbgebung auch mit verschiedenen Populationen in Verbindung gebracht, wobei die nord- und mitteleuropäischen Populationen als rötlicher beschrieben wurden als die des Mittelmeerraums. Eine Untersuchung in den Pyrenäen zeigte, dass Tiere mit längeren Flügeln eine offenbar geringere Überlebensrate und einen höheren Anteil an rötlichen Individuen aufwiesen, woraus zu schließen wäre, dass es sich um nomadisierende Vögel handeln könnte (die weite Strecken zurücklegen). Wenn die roten Fichtenkreuzschnäbel mobiler als die gelben und orangefarbenen sind, könnte ihre Überlebensrate mutmaßlich geringer sein. Aber in unserer Untersuchung lebten rötliche Männchen länger als andersgefärbte und fast doppelt so lang wie die gelblichen Männchen. Diese Ergebnisse deuten darauf hin, dass die rote Färbung mit höherwertigen Individuen verbunden ist, unabhängig von deren Mobilität.

\section{Introduction}

Communicated by F. Bairlein.

Blanca Fernández-Eslava

bfernandez@alumni.unav.es

1 Department of Environmental Biology, Universidad de Navarra, 31008 Pamplona, Spain

2 Department of Ornithology, Aranzadi Sciences Society, Zorroagagaina 11, 20014 Donostia-San Sebastián, Spain
Avian coloration largely depends on pigments deposited in plumage or bare parts (Prum 1999). Carotenoid pigments generate conspicuous yellow, orange, and red colorations in many avian species (Fox 1976; Stradi et al. 1996). These colours depend not only on pigment concentration but also on the specific nature of each carotenoid compound (Hill et al. 2002). Some species metabolize the yellow carotenoids present in the diet into red carotenoids to develop orange or 
redder traits (Stradi 1998; Stradi et al. 1996; reviewed in McGraw 2006).

Carotenoid-based colorations in animals have apparently evolved as signals revealing the quality of an individual in social or sexual selection contexts (e.g. Svensson and Wong 2011). The link to individual quality could be sustained by the variety of important physiological functions where carotenoids are involved (e.g. Lozano 1994; Olsen and Owens 1998; Möller et al. 2000). The transformation of yellow pigments into red ones was firstly considered energetically costly, which would favour the signal reliability (Hill 2000). It has also been suggested that this transformation would depend on the availability of yellow dietary carotenoids, thus causing a trade-off between investing them in critical physiological functions (immunity or antioxidant defence) instead of coloration, which would also favour the honesty of red sexual signals (von Schantz et al. 1999; Moller et al. 2000; Alonso-Alvarez et al. 2008). Finally, carotenoid transformation has also been linked to mitochondrial metabolism (cell respiration; Hill 2011; Johnson and Hill 2013). In this case, red ornaments indicate the intrinsic quality of an individual as it would be unable to regulate (balance) its expression regarding to any other function (i.e. individuals could not be able to cheat about its capacity to express colour; Hill 2011; Johnson and Hill 2013).

Red Crossbills (Loxia curvirostra; hereafter, Crossbill) comprise a broadly distributed species complex, breeding from Europe to Asia (incl. northern Africa, Middle East, the Himalayas, and some areas in Southeast Asia), and the northern half of America (and Nicaragua) (Collar et al. 2010). They are associated with coniferous woodlands and are adapted to feeding on their seeds, taken from still closed cones using their specialised bills (Benkman 1987, 1993; Benkman and Lindholm 1991). Male Crossbills show head, underparts, and rump red, but some have variable amounts of yellow-orange; and some are fully yellow, without any visible red feathers (Cramp and Perrins 1994). Both the intensity and the proportion of red-yellow-orange birds differ geographically (e.g., Massa 1987) but also seasonally within areas (Alonso and Arizaga 2013). In general, it is stated that red is the most 'expensive' colour that a Crossbill is able to produce because the red coloration arises from yellow carotenoids already present in the diet but only if conditions linked to oxidative processes happen (Stradi 1998; Inouye 1999; García de Blas et al. 2016; Vaugoyeau et al. 2015). This oxidation occurs only in some individuals (e.g., Vaugoyeau et al. 2015). Previous research showed that redder Crossbills were more common in long-winged males as compared to males with shorter wings, and long-winged Crossbills were also detected to have lower apparent survival rates than short-winged Crossbills (Alonso and Arizaga 2013). This work suggests that in the Pyrenees, a fraction of Crossbills, presumably more mobile (as they had long wings) and more red in colour had a higher chance of abandoning the area and, therefore, giving rise to a lower apparent local survival (Alonso and Arizaga 2013). However, a direct link between colour pattern and survival has never been tested. Whether the red Crossbills are more mobile than the yellow-orange ones, as suggested in previous research (Alonso and Arizaga 2013), it can be hypothesized that apparent survival will be lower in the red Crossbills, as compared to those with paler colour patterns (yellow or orange). However, if we consider that the redder crossbills could have higher individual quality (see above), we should predict that they would also have higher survival than less red individuals.

\section{Material and methods}

\section{Sampling area and data collection}

The data used in this work were collected in Uztarroz $\left(42^{\circ}\right.$ $52^{\prime} \mathrm{N} 1^{\circ} 00^{\prime} \mathrm{W} ; 1383 \mathrm{~m}$ a.s.1.), a Pyrenean locality in Navarra (North of Spain), situated in extensive woodlands of Scots pine (Pinus sylvestris). This locality host, apparently (or partly) resident Crossbill populations that can be captured across the whole annual cycle (Alonso and Arizaga 2011, 2017). The breeding season of these populations lasts from December to June, with the peak occurring from February to March/April (when we detect a higher proportion of females with fully formed brood patches) (Alonso and Arizaga 2011). Thereafter, a facultative, second breeding period can occur in summer, from July to September, but this does not have the importance (in terms of breeding birds and years) of the main breeding season in late winter/spring (Alonso and Arizaga 2011). For our analyses, we selected only the data obtained from January to April when Crossbills were more abundant and stationary in the area.

The sampling site was visited once every $2-4$ weeks over the years 1993-2019. Crossbills were captured using mist nets (usually 12 linear metres) that remained open for a period of $4 \mathrm{~h}$ from dawn. The nets were placed always in a same, fixed place, situated in a zone regularly used by crossbills to ingest salt (minerals) (Alonso and Arizaga 2005).

Once captured, crossbills were ringed, and their age and sex were noted (Svensson 1996). Juveniles undergo a partial moult and adults complete moult. Hence, in general, birds with some retained juvenile feathers in their body and wings or tails were aged as first-year birds (EURING 3 or 5 , depending on whether they were captured in their first or second-calendar year), and birds with all adult feather were aged as adults (EURING 6 or older) (Jenni and Winkler 1994). In those birds which were recaptured once or more, we aged them according to the age they had in their first capture event. After determining sex and age, we also measured 
some biometric variables, but we only use the wing length in this work to control the possible dispersion effect. We also recorded the colour of each as red, orange or yellow. The latter comprised birds either pure yellow or a variable number of yellow and red/orange feathers ('patched' birds), although pure-yellow birds were relatively scarce. This visual assessment of the colour correlated very well with colour measures recorded by colorimetry (Del Val et al. 2009a). Furthermore, an analysis with four-colour categories showed high repeatability (Spearman's $R=0.96, P<0.001$; Cantarero et al. 2020). In this case, we use three categories (we mixed pure yellow and patchy birds) but we assume that the repeatability is also high. A single observer (DA) recorded all measurements, including colour group.

\section{Statistical analyses}

Apparent survival values were assessed with Cormack-JollySeber (CJS) models in MARK (White and Burnham 1999). These models permit estimating apparent survival $(\varphi$; i.e., the fact that a bird captured in time $t$ survives to $t+1)$ and the probability of recapture ( $p$; i.e., it is the probability that a marked individual that is alive at $t+1$ is captured at $t+1$.) separately.

The analyses were restricted to reproductive males (subadults EURING 5, and adults EURING 6 or older), that is, individuals from the second year onwards with at least their partial moult completed. Juvenile individuals were discarded since they still lack the typical red to yellow coloration in the plumage, also those birds with their first partial moult still unfinished. Thus, our data set was a matrix of captures (or recaptures) obtained in a period of 27 years (from 1993 to 2019), with a sample size of 1799 adult males in which the colour had been determined using the categorical code of three levels described above.

Crossbills can change colour with each moult event. Part of those changes occurs in EURING 5 individuals (i.e. birds in their second year of life when making their first complete moult) (CITAS). In this study we have verified that there is higher proportion of red birds among those aged as 6 (yellows: $27.7 \%$, oranges: $25.8 \%$, reds: $46.5 \%$ ) than among those aged as 5 (yellows: $29.5 \%$, oranges: $29.8 \%$, reds: $40.7 \%)\left(\chi^{2}=6.37, P=0.04\right)$. This is because a proportion of birds moult to red when they undergo their first complete moult. In our case, 30 subadults individuals of 101 recaptures change their colour (from the colour of the first capture to its maximum colour). Furthermore, a colour shift in senescence towards less red colours is also possible (unpublished data). For survival analyses, we selected the maximum colour category (assuming that the natural order in relation to the largest amount of red carotenoids is yellow, orange, and red) of all captured crossbills to minimize biases. Even and everything, there may be some bias due to
Table 1 Chi-squared test between the colour of the first and last captures for subadults $\left(\chi^{2}=3.9636, \mathrm{~d} f=2, p\right.$ value $\left.=0.1378\right)$ and adults $\left(\chi^{2}=2, \mathrm{~d} f=2, p\right.$ value $\left.=0.3679\right)$

\begin{tabular}{llllll}
\hline & & & Yellow & Orange & Red \\
\hline Subadults & Initial colour & Observed & 35 & 24 & 47 \\
& & Expected & 37.5 & 18.5 & 50 \\
& & Residuals & -0.408 & 1.279 & -0.424 \\
& \multirow{4}{*}{ Final colour } & Observed & 40 & 13 & 53 \\
& & Expected & 37.5 & 18,5 & 50 \\
\multirow{4}{*}{ Adults } & Initial colour & Residuals & 0.408 & -1.279 & 0.424 \\
& & Observed & 15 & 21 & 34 \\
& & Expected & 18 & 18 & 34 \\
& \multirow{4}{*}{ Final colour } & Residuals & -0.707 & 0.707 & 0 \\
& & Observed & 21 & 15 & 34 \\
& & Expected & 18 & 18 & 34 \\
& & Residuals & 0.707 & -0.707 & 0 \\
\hline
\end{tabular}

colour change of individuals. For example, it is likely that a percentage of individuals in the yellow group will turn red (after their first complete moult). In addition, part of the yellow birds could come from birds being red previously (e.g. due to senescence). The effect of these biases would be an increasing amount of variance, and hence a lower capacity to detect significant differences. Assuming this, we have no way to address this (potential) bias, but the existence of significant differences on survival among colour types would certainly support the existence of a real biological effect. On the other hand, a chi-square test showed no significant changes between the colour of the first and last captures (Table 1), supporting our field experience which suggests that individual colour keeps rather constant over time.

Before starting a selection process including different alternative models, we tested for the fit of the data to CJS assumption, for which the U-CARE software was run (Choquet et al. 2009). A global goodness of fit test showed that the data fitted CJS assumptions $\left(\chi^{2}=16.93, \mathrm{~d} f=86, P \sim 1\right)$, as either fitted the specific test to detect transients (statistic: $1.05 ; P=0.146$ ), or trap-dependence (statistic: 0.56 ; $P=0.578$ ). Therefore, the presence of transients (sensu Pradel et al. 1997) was not considered when models were built. Our basic model from which to start to build alternative, more complex models was $\varphi, p$ (i.e., constant $\varphi$ and $p)$. Starting from here, we then tested for models assuming constant or time-dependence on $\varphi$ and $p$, and for a colour, age (i.e., crossbills aged as EURING 5 or 6 in their first capture event) or wing length (this last used as a covariate) effect on $\varphi$. Wing length was used to control effect dispersal as a covariate since we found in previous studies that survival was correlated with wing length (Alonso and Arizaga 2013), as well as that wing length is correlated with colour (Fernández-Eslava, unpubl. data). All possible models were 
Table 2 Ranking of the Cormack-Jolly-Seber models run to determine the effect of the colour on apparent survival of a Red Crossbill population

\begin{tabular}{llrlrc}
\hline Model & AICc & $\Delta$ AICc & AICc weight & $n p$ & Deviance \\
\hline$\varphi$ (colour $\times$ age $\times$ wing), $p(t)$ & 1515.59 & 0.00 & 0.99 & 35 & 1444.28 \\
$\varphi$ (colour $\times$ age), $p(t)$ & 1525.76 & 10.17 & 0.01 & 29 & 1466.86 \\
$\varphi$ (colour), $p(t)$ & 1540.16 & 24.57 & 0.00 & 26 & 1487.43 \\
$\varphi$ (wing $\times$ age), $p(t)$ & 1563.98 & 48.39 & 0.00 & 27 & 1509.20 \\
$\varphi$ (age), $p(t)$ & 1575.88 & 60.29 & 0.00 & 25 & 1525.21 \\
$\varphi, p(t)$ & 1587.83 & 72.24 & 0.00 & 24 & 1539.21 \\
$\varphi$ (wing), $p(t)$ & 1589.83 & 74.24 & 0.00 & 25 & 1539.16 \\
$\varphi(\mathrm{t}), p(t)$ & 1598.59 & 83.00 & 0.00 & 41 & 1514.80 \\
$\varphi(\mathrm{t}), p$ & 1615.53 & 99.94 & 0.00 & 23 & 1568.96 \\
$\varphi, p$ & 1703.20 & 187.61 & 0.00 & 2 & 1699.19 \\
\hline
\end{tabular}

AIC small-sample sizes-corrected Akaike value; $\triangle A I C c$ difference of AICc values in relation to the top, first ranked model; $n p$ number of parameters; $t$ time-dependence; $\varphi_{1}$ and $\varphi_{2}$ apparent survival varies between two age classes (first-year birds and adults) ranked in relation to their small-sample size Akaike values (AICc), and then those differing in less than 2 AICc units were considered to fit the data equally well (Burnham and Anderson 1998).

\section{Results}

The first ranked model, hence the one that best fitted the data, considered an effect of colour, age and wing length on apparent survival (Table 2). Apparent survival showed increasing values from yellow to red, and for crossbills aged as subadults as compared to adults (Fig. 1). Regarding wing length, we observed that the wing-survival relationship differed between age classes and colour categories (Fig. 2). Overall, apparent survival tended to be low and did not vary significantly with wing length for yellow crossbills. On the opposite, apparent survival in orange and red crossbills covaried positively with length in subadults birds (EURING 5), but negatively in adults birds (EURING 6 or older) (Fig. 2).

Regarding the probability of recapture $(p)$, the bestranked models supported time-dependence of $p$, as also did the first model. Overall, the annual $p$ values ranged from $0.018 \pm 0.018$ to $0.42 \pm 0.06($ mean $=0.16)$.

\section{Discussion}

To our knowledge, this is the first study where the apparent survival of wild male Crossbills is calculated in relation to their colour pattern, ranging from yellow to red. Male crossbills with bright red plumage showed greater apparent survival than orange and yellow birds (ca. as higher as twice for orange birds with intermediate values) in both subadults (EURING 5) and adults (EURING 6 or older) birds (Fig. 2).
Overall, therefore, a link between colour pattern and apparent survival is proven, regardless of whether the colour has a direct or indirect impact on apparent survival (e.g., if survival is linked with other processes which have a link with coloration).

In other birds, the expression of carotenoids in male ornaments also had an association with survival (Hõrak et al. 2001; Simons et al. 2012; Cantarero et al. 2019), hence supporting the view that redder males were those with a higher individual quality (Weaver et al. 2018). In male crossbills, the carotenoid-based red coloration originates from the ingestion of yellow carotenoids (mostly $\beta$-cryptoxanthin) that are subsequently converted into red ketocarotenoids (3-hydroxy-echinenone; Del Val et al. 2009b; Cantarero et al. 2020). In line with this, Cantarero et al. (2020) found that some carotenoids provided to crossbills made the plumage red, but this was only possible in those individuals already red at the beginning of the experiment were also treated with a mitochondrial-targeted antioxidant. These authors, therefore, suggested that it was not only the diet, but also the mitochondrial metabolism of each bird, that explained the coloration. Hence, red coloration would be closely linked to individual quality in terms of cell respiration (see Hill 2011; Johnson and Hill 2013; Cantarero et al. 2020). In our Crossbill population, our results were consistent with the idea that red males may be those with a higher individual quality, because they showed significantly higher apparent survival rates. Under this rationale, the effort made to convert yellow pigments into red may have no impact on survival, given that these red males showed better survival than the yellow ones. This should be only possible if those males able to be red may be individuals of the highest quality. Otherwise, such an effort should be associated with a cost (lower survival rates) in the red males, which could then be similar to the survival found among the orange and yellow Crossbills. 
Fig. 1 Mean $( \pm 95 \% \mathrm{CI})$ apparent survival (parameter: $\varphi$ from the top-ranked model in Table 2)
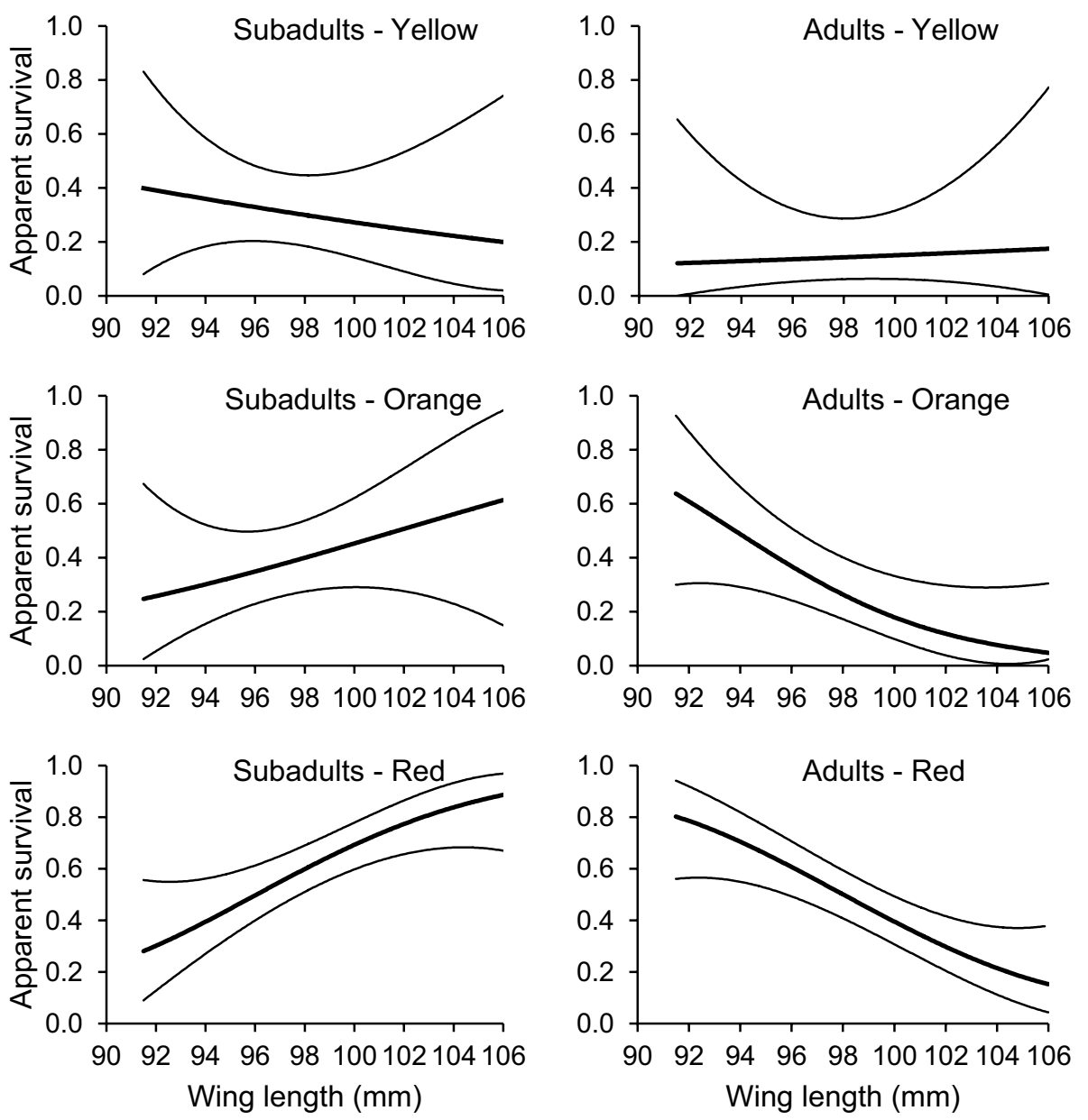

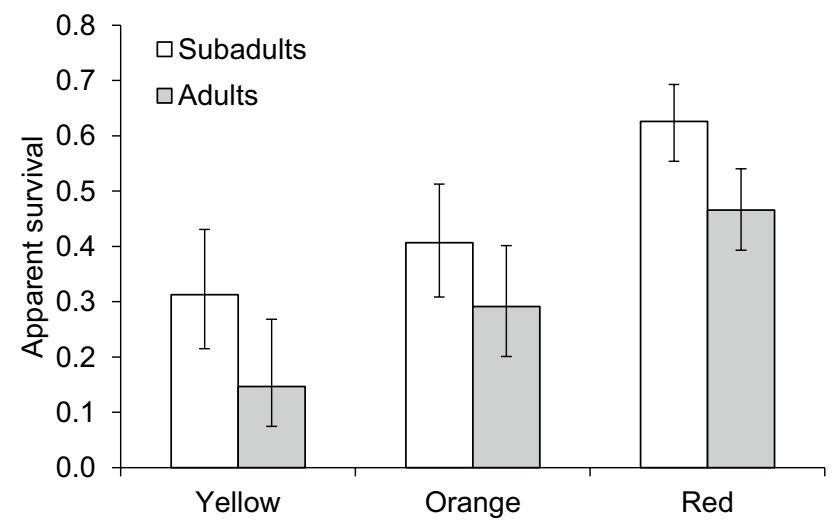

Fig. 2 Mean $( \pm 95 \% \mathrm{CI})$ apparent survival (parameter: $\varphi$ from the second top-ranked model in Table 2) of male Common Crossbills of different dominant coloration captured during a 27 -year period at a locality in Pyrenees (Spain)

Therefore, the redder crossbills would survive better as their cell respiratory metabolism is superior to that in those individuals only able to produce yellow feathers. The fact that an inefficient cell respiration is usually linked to ageing-related pathologies in vertebrates (e.g. Barja 2014;
Dawson and Salmon 2020) may explain the lower apparent survival probabilities of yellow crossbills. We should also note that, even when plumage colour can potentially change throughout lifetime in crossbills (Fernandez-Eslava et al. unpublished), the trait would anyway transmit a reliable information on individual quality at each life history period. In other words, one bird could be the best (reddest) one in middle-age but not in elderly.

In terms of reliability of our survival measure, the same technique used in another study carried out in the same two populations (i.e. Alonso and Arizaga 2013) showed that survival was lower among crossbills with longer wings. Thus, long-winged birds could migrate more (more nomadic), giving the impression of lower survival. This implies that the addition of the wing length to the models (Table 2) might have, at least partially, controlled for the effect of dispersal.

Interestingly, long-winged birds in Alonso and Arizaga (2013) were also found to be composed of a higher proportion of red individuals. In that study, only birds aged as EURING 6 (or older individuals) were considered. Our results are in the same line (Fig. 1). Long-wing birds could belong to another population which could come either from northern Europe (e.g., during irruptions to southern Europe) 
(Newton 2006) or from other areas from the Pyrenees (Arizaga et al. 2014; Alonso et al. 2017). Interestingly, this rule did not fit for those birds aged as EURING 5, where we found exactly the opposite pattern (i.e. longer wings, higher apparent survival; Fig. 1). We link this result to the fact that the proportion of local birds, here understood as those hatching within the region, is likely to be higher in crossbills aged as EURING 5. The lack (or marginal proportion) of nomads in this age group may explain why longerwinged birds showed higher apparent survival. In this case, we should assume that these larger birds are high-quality (maybe larger) individuals. Future research should delve into this particular phenomenon, which could hide complex processes between crossbills of different age groups and colours, in terms of population dynamics.

In addition to the differences between coloration and wing length, different survival between ages is observed. Subadults individuals have greater survival than adults. It could be because within adult group, we include birds of several years, older birds, with a shorter life expectancy. That is, we are putting the effect of senescence in survival estimates (Fay et al 2020).

In summary, red coloured crossbills had higher apparent survival rates, which might show either higher real survival (i.e., greater individual quality) or residency than yellow crossbills. However, apart from these effects, we also learnt that apparent survival covaried negatively with wing length in the adults red crossbills (EURING 6 or older), suggesting possible emigration of the longer-winged birds. In contrast, this relationship was negative for those subadults birds (EURING 5). We attribute this effect to a possibly higher proportion of crossbills hatched within the region in this last age group.

Acknowledgements We are grateful to the people who collaborated with us during the fieldwork, particularly to A. Mendiburu and J. Barbarin. Also to C. Alonso-Alvarez and two anonymous reviewers who provided valuable comments that helped improve an earlier version of the manuscript. Birds were captured thanks to the permits granted by the corresponding authorities of Gobierno de Navarra.

Author contributions All the authors participated in the conception and design of the work: BF, DA and JA conceived the ideas and designed methodology; DA collected the data; BF and JA analysed the data; BF, DG and JA led the writing of the manuscript.

Funding Open Access funding provided thanks to the CRUE-CSIC agreement with Springer Nature.

Open Access This article is licensed under a Creative Commons Attribution 4.0 International License, which permits use, sharing, adaptation, distribution and reproduction in any medium or format, as long as you give appropriate credit to the original author(s) and the source, provide a link to the Creative Commons licence, and indicate if changes were made. The images or other third party material in this article are included in the article's Creative Commons licence, unless indicated otherwise in a credit line to the material. If material is not included in the article's Creative Commons licence and your intended use is not permitted by statutory regulation or exceeds the permitted use, you will need to obtain permission directly from the copyright holder. To view a copy of this licence, visit http://creativecommons.org/licenses/by/4.0/.

\section{References}

Alonso D, Arizaga J (2005) Efecto de la edad, el sexo y el tiempo en la biometría del piquituerto común (Loxia curvirostra curvirostra) en Navarra. Munibe 56:133-144

Alonso D, Arizaga J (2011) Seasonal patterns of breeding, moulting, and body mass variation in Pyrenean Common Crossbills Loxia curvirostra curvirostra. Ringing Migr 26:64-70

Alonso D, Arizaga J (2013) The impact of vagrants on apparent survival estimation in a population of Common Crossbills (Loxia curvirostra). J Ornithol 154:209-217

Alonso D, Arizaga J (2017) Dinámica estacional de la abundancia de piquituerto común Loxia curvirostra L., 1756 en dos localidades del Pirineo Navarro e implicaciones para su seguimiento mediante anillamiento. Munibe 65:95-105

Alonso D, Arizaga J, Meier CM, Liechti F (2017) Light-level geolocators confirm resident status of a Southern European Common Crossbill population. J Ornithol 158:75-81

Alonso-Alvarez C, Perez-Rodriguez L, Mateo R, Chastel O, Viñuela $\mathrm{J}$ (2008) The oxidation handicap hypothesis and the carotenoid allocation trade-off. J Evol Biol 21:1789-1797. https://doi.org/ 10.1111/j.14209101.2008.01591.x

Arizaga J, Alonso D, Hobson K (2014) Disentangling the origin of crossbills using morphology and isotopic $(\delta 2 \mathrm{H})$ characters. Are southern European crossbills restricted to population-specific key resources? J Ornithol 155:1027-1035

Barja G (2014) The mitochondrial free radical theory of aging. Prog Mol Biol Transl Sci 127:1-27. https://doi.org/10.1016/B978-012-394625-6.00001-5

Benkman CW (1987) Crossbill foraging behaviour, bill structure, and patterns of food profitability. Wilson Bull 99:351-368

Benkman CW (1993) Adaptation to single resources and the evolution of crossbill (Loxia) diversity. Ecol Monogr 63:305-325

Benkman CW, Lindholm AK (1991) The advantages and evolution of a morphological novelty. Nature 349:519-520

Burnham KP, Anderson DR (1998) Model selection and inference. A practical information theoretic approach. Springer-Verlag, New York

Cantarero A, Pérez-Rodríguez L, Romero-Haro AÁ, Chastel O, Alonso-Alvarez C (2019) Carotenoid-based coloration predicts both longevity and lifetime fecundity in male birds, but testosterone disrupts signal reliability. PLoS One 14:e0221436

Cantarero A, Mateo R, Camarero PR, Alonso D, Fernandez-Eslava B, Alonso-Alvarez C (2020) Testing the shared-pathway hypothesis in the carotenoid-based coloration of red crossbills. Evolution 74:2348-2364. https://doi.org/10.1111/evo.14073

Choquet R, Lebreton JD, Gimenez O, Reboulet AM, Pradel R (2009) U-CARE: utilities for performing goodness of fit tests and manipulating Capture-Recapture data. Ecography 32:1071-1074

Collar NJ, Newton I, Clement P (2010) Family Fringillidae (Finches). In: Del Hoyo J, Elliot A, Christie DA (eds) Handbook of the Birds of the World, vol 15. Lynx, Barcelona, pp 440-617

Cramp S, Perrins CM (1994) Handbook of the Birds of Europe, the Middle East and North Africa, vol 8. Oxford University Press, Oxford

Dawson NJ, Salmon P (2020) Age-related increase in mitochondrial quantity may mitigate a decline in mitochondrial quality in red 
blood cells from zebra finches (Taeniopygia guttata). Exp Gerontol 133:110883

Del Val E, Borras A, Cabrera J, Senar JC (2009a) Plumage colour of male Common Crossbills Loxia curvirostra: visual assessment validated by colorimetry. Revista Catalana D'ornitologia 25:19-25

Del Val E, Senar JC, Garrido-Fernández J, Jarén M, Borràs A, Cabrera J, Negro JJ (2009b) Hepatic conversion of red carotenoids in passerine birds. Naturwissenschaften 96:989-991

Fay R, Schaub M, Border JA, Henderson IG, Fahl G, Feulner J, Horch P, Müller M, Rebstock H, Shitikov D, Tome D, Vögeli M, Grüebler MU (2020) Evidence for senescence in survival but not in reproduction in a short-lived passerine. Ecol Evol 10:5383-5390. https://doi.org/10.1002/ece3.6281

Fox DL (1976) Animal biochromes and structural colours. University of California Press, Berkeley

García-de Blas E, Mateo R, Alonso-Alvarez C (2016) Specific carotenoid pigments in the diet and a bit of oxidative stress in the recipe for producing red carotenoid-based signals. PeerJ 4:e2237. https://doi.org/10.7717/peerj.2237

Hill GE (2000) Energetic constraints on expression of carotenoid-based plumage coloration. J Avian Biol 31:559-566. https://doi.org/10. 1034/j.1600-048X.2000.310415.X

Hill GE (2011) Condition-dependent traits as signals of the functionality of vital cellular processes. Ecol Lett 14:625-634. https://doi. org/10.1111/j.1461-0248,2011.01622.x

Hill GE, Inouye C, Montgomerie R (2002) Dietary carotenoids predict plumage coloration in wild house finches. Proc Biol Sci 269:1119-1124

Hõrak P, Ots I, Vellau H, Spottiswoode C, Møller AP (2001) Carotenoid-based plumage coloration reflects hemoparasite infection and local survival in breeding great tits. Oecologia 126:166-173. https://doi.org/10.1007/s004420000513

Inouye CY (1999) The physiological bases for ca- rotenoid color variation in the House Finch, Car- podacus mexicanus. Ph.D. dissertation. University of California, Los Angeles

Jenni L, Winkler R (1994) Moult and ageing of European passerines. Academic Press, London

Johnson JD, Hill G (2013) Is carotenoid ornamentation linked to the inner mitochondria membrane potential? A hypothesis for the maintenance of signal honesty. Biochimie 95:436-444

Lozano G (1994) Carotenoids, parasites, and sexual selection. Oikos 70:309-311. https://doi.org/10.2307/3545643

Massa B (1987) Variations in Mediterranean Crossbills Loxia curvirostra. Bull Brit Orn Club 107:118-129

McGraw KJ (2006) Mechanics of carotenoid-based coloration. In: Hill GE, McGraw KJ (eds) Bird coloration. Mechanisms and measurements, vol 1. Harvard University Press, Cambridge, pp 177-242
Møller AP, Biard C, Blount JD, Houston DC, Ninni P, Saino N, Surai PF (2000) Carotenoid-dependent signals: indicators of foraging efficiency, immunocompetence or detoxification ability? Avian Poult Biol Rev 11:137-159

Newton I (2006) Movement patterns of Common Crossbills Loxia curvirostra in Europe. Ibis 148:782-788

Olson VA, Owens IPF (1998) Costly sexual signals: are carotenoids rare, risky or required? Trend Ecol Evol 13:510-514

Pradel R, Hines JE, Lebreton JD, Nichols JD (1997) Capture-recapture survival models taking account of transients. Biometrics 53:60-72

Prum RO (1999) The anatomy and physics of avian structural colours. In. Adams and R. Slotow (ed.), Proceedings of the 22nd International Ornithological Con- gress, S29.1: 1633-1653. Durban, South Africa: Bird Life South Africa

Simons MJ, Briga M, Koetsier E, Folkertsma R, Wubs MD, Dijkstra C, Verhulst $S$ (2012) Bill redness is positively associated with reproduction and survival in male and female zebra finches. PLoS One 7(7):e40721. https://doi.org/10.1371/journal.pone.0040721

Stradi R (1998) The colour of flight: carotenoids in bird plumages. Solei Gruppo Editoriale Informatico

Stradi R, Rossi E, Celentano G, Bellardi B (1996) Carotenoids in bird plumage: the pattern in three Loxia species and in Pinicola enucleator. Comp Biochem Physiol B 113:427-432

Svensson L (1996) Guía para la identificación de los paseriformes europeos. Sociedad Española de Ornitología, Madrid

Svensson P, Wong B (2011) Carotenoid-based signals in behavioural ecology: a review. Behaviour 148: 131-189. http://www.jstor.org/ stable/25799805. Accessed 9 Nov 2020

Vaugoyeau M, Decencière B, Perret S, Karadas F, Meylan S, Biard C (2015) Is oxidative status influenced by dietary carotenoid and physical activity after moult in the great tit (Parus major)? J Exp Biol 218:2106-2115. https://doi.org/10.1242/jeb.111039

Von Schantz T, Bensch S, Grahn M, Hasselquist D, Wittzell H (1999) Good genes, oxidative stress and condition-dependent sexual signals. Proc R Soc Lond B 266:1-12

Weaver RJ, Santos ESA, Tucker AM, Wilson AE, Hill GE (2018) Carotenoid metabolism strengthens the link between feather coloration and individual quality. Nat Commun 9:73. https://doi.org/ 10.1038/s41467-017-02649-z

White GC, Burnham KP (1999) Program MARK: survival estimation from populations of marked animals. Bird Study 46:120-139

Publisher's Note Springer Nature remains neutral with regard to jurisdictional claims in published maps and institutional affiliations. 